10. Vereitina, I., Baidak, Yu. (2015). Virtual educational environment and activation of students professional and creative potential. Proceedings of the conference: Contemporary innovation technique of the engineering personnel training for the mining and transport industry. Ukraine, Dnepropetrovsk. 285-292.
11. Gattengo, C. (1972). Teaching Foreign Languages in Schools: The Silent Way. 2nd ed. NX-Educational Solutions. $152 \mathrm{p}$.

12. Larsen, Freeman D. (1986). Techniques and Principles in Language Teaching. Oxford: Oxford Univ. Press. $142 \mathrm{p}$.

\title{
БАЙДАК Юрій,
}

доктор технічних наук, професор, кафедра термодинаміки та відновлюваної енергетики,

Одеська національна академія харчових технологій

e-mail: yuribaydak@ukr.net

BEPEITIHA Iрина,

кандидат педагогічних наук, доцент, кафедра іноземних мов,

Одеська національна академія харчових технологій e-mail:kozak_admin@ukr.net

ПОПЕАЬ Оксана,

кандидат педагогічних наук, доцент, кафедра іноземних мов,

Одеська національна академія харчових технологій e-mail: ksenjapope12580@gmail.com

\section{ВІРТУААЬНЕ ОСВІТНЄ СЕРЕДОВИЩЕ ДАЯ ЦІАЕЙ НАВЧАННЯ}

\begin{abstract}
Анотаиія. Нині система підготовки майбутніх інженерів переходить на новий етап свого розвитку та відкривае нові горизонти - пов'язані з формуванням плюралізму в освіті, розробкою нових методів навчання, чо призводять до появи нових підходів до навчального проиесу та необхідності впровадження нових технологій, які повинні підтримувати мотиваиію студентів до навчання протягом усъого життя та стимулювати їх творчість. Е-навчання, т-навчання, інтерактивні електронні книги, віртуальні навчальні реалї - такі неологізми постійно інтегруються в усі сфери освіти, а інженерне навчання не є винятком.

Метою роботи $\epsilon$ визначення основних методологічних та психологічних засад створення та впровадження віртуального освітнього середовииа.

охарактеризовано сутнісні особливості кониепиії "віртуального навчального середовиша" та надано його фундаментальні властивості
\end{abstract}

у статті розглянуто основні аргументи "за" та "проти" використання віртуального освітнього середовища у проиесі навчання.

Педагогічна система, яка застосовує віртуальне навчальне середовище, повинна розглядатися як ситуативна, оскільки особливості ї̈ застосування визначаються кожного разу за спеиифічними умовами навчання та віртуальною освітньою ситуаиією, яка існує лише в иій області, в ией час, міжк конкретними суб'єктами та об'єктами освіти. Необхідність розробки спеиіальної дидактики для віртуальних навчальних середовиш очевидна. Необхідно створити та запровадити віртуальні навчальні середовища для кожної дисиипліни

Ключові слова: електронне навчання; навчання; інтерактивна електронна книга; віртуальне середовише навчання.

Одержано редакиією 22.06.2018 Прийнято до публікаиї 30.06.2018

DOI 10.31651/2524-2660-2018-14-9-17

ORCID 0000-0001-6263-4744

\section{ВІНТЮК Юрій Володимирович,}

кандидат психологічних наук, доцент кафедри теоретичної та практичної психології, Національний університет "Аьвівська політехніка",

УДК 377.3.015.31 : 159.9-051 e-mail: yurvin@ukr.net

\section{РОЗРОБКА НАВЧААЬНОГО СПЕЦКУРСУ "ПСИХОАОГІЯ КОНКУРЕНТОСПРОМОЖНОÏ ОСОБИСТОСТІ}

У статті розглянуті можливості підвишення конкурентоспроможності майбутніх фахових психологів у проиесі їхнього навчання в ВНЗ. Сформульовані вихідні передумови даного дослідження; зроблений огляд наукових публікаиій за даною темою, в результаті з'ясовані погляди фахівиів на дану проблему і можливості ї̈ вирішення. На основі отриманих даних сформований раиіональний підхід до вирішення вказаної проблеми; з його використанням розроблений спеикурс, призначений для формування конкурентоспроможності майбутніх психологів у проиесі їхнъого навчання в ВНЗ. Наведено інформацію про апробаиію розробленого спецкурсу. Зроблені висновки з проведеного дослідження й накреслені перспективи подальших досліджень у даному напрямку.
Ключові слова: підготовка майбутніх фахових психологів; діяльність у ринкових умовах; ринок праиі; конкурениія; навчальний спецкурс; психологія конкурентоспроможної особистості; оптимізаиія проиесу підготовки фахівиів.

Постановка пробиеми. Необхідність діяльності у сучасних умовах ринкової економіки вимагає зміни підходів до процесу підготовки фахівців різного профілю. Це стосується практично всіх сорер діяльності, зокрема, фахових психологів, які змушені працювати за реамій, коли їхні послуги ще не достатньо затребувані нашим суспільством. У ная- 
вній ситуації професійному практичному психологу потрібно не мише мати належний рівень фахової компетентності, йому також необхідно знайти відповідну сферу для прикладання своїх знань і вмінь, оскільки у попередні десятиліття психомоги не були представцені у різних галузях народного господарства. Проте наша країна, яка постала перед викликами світової спільноти і ії економічної системи, вимагає інтенсифікації процесів суспільного розвитку, що зумовлює необхідність впровадження професії психолога у найрізноманітніші сфери діяльності. А головною умовою адаптації до наявних реалій $\epsilon$ формування високої конкурентоспроможності, як всіх галузей господарства, так і окремих фахівців, різного профілю, практичних психологів зокрема. Звідси слідує необхідність таким чином організувати процес підготовки психологів у вітчизняних ВНЗ, щоб майбутні фахівці були здатними до діяльності в умовах конкуренції на ринку праці.

Проблема, що перебуває у центрі розгляду в даній роботі, може бути сформуцьована наступним чином: навіть за наявності належного рівня фахової компетентності професійні психологи часто не можуть належним чином адаптуватися до наявних суспільних реалій і організувати діяльність в умовах конкуренції, зокрема, через те, що ї не готують до цього у ВНЗ; необхідність пошуку шияхів iї вирішення зумовлює актуальність даного дослідження.

Мета роботи: З'ясувати наявні можАивості підвищення конкурентоспроможності майбутніх фахових психологів у процесі їхного навчання у ВНЗ, виробити і реалізуватираціональний підхід для створення відповідного навчального спецкурсу і розробити такий спецкурс.

\section{Завдання досмідження:}

- сфрормулювати вихідні передумови дослідження;

- зробити огляд наукових публікацій за даною темою, з'ясувати погляди фахівців на вказану проблему і можливості іiі вирішення;

- на основі одержаних даних сформувати раціональний підхід до вирішення даної проблеми;

- використовуючи ссормований підхід розробити навчальний спецкурс, призначений для формування конкурен- тоспроможності майбутніх психологів у процесі їхнього навчання у ВНЗ;

- провести апробацію розробленого навчального спецкурсу;

- зробити висновки 3 проведеного дослідження і намітити перспективи подальших досліджень у даному напрямку.

Передусім необхідно відзначити, що підвищення конкурентоспроможності майбутніх фахових психологів здійснюється в процесі навчання у ВНЗ, оскільки в ході нього відбувається розвиток їхньої професійної компетентності. Проте, оскімьки результати найчастіше далекі від бажаних, для оптимізації та інтенсифікації цього процесу видається доречним впровадження в навчальний процес спецкурсу, який мав би зробити хід формування конкурентоспроможності майбутніх фахових психологів усвідомленішим і цілеспрямованішим.

Початково планувалося скласти психологічний портрет особистості конкурентоспроможного фахівця шияхом з'ясування ряду психологічних особливостей, для чого передбачалося послідовно висвітлити наступні аспекти проблеми: філософський (а саме світоглядний його компонент); а також соціальний і педагогічний - що дозволило б скласти загальне уявлення про предмет розгляду. Після цього планувалося ретельно розглянути психологічний аспект, передусім наступні його компоненти: мотиваційний, інте^ектуальний, креативнісний, когнітивний, комунікативний, афективний, поведінковий, особистісний, компетентнісний та ін.

Проте, як з'ясувалося, 3 окремих складових практично не можливо скласти цілісний психологічний портрет конкурентоспроможної особистості, ні зрозуміти хід іiі формування, а тим більше встановити закономірності взаємодії перелічених компонентів у процесі виховання, навчання, професійної підготовки і подальшої діяльності тощо. Звідси постала необхідність розглядати не окремі компоненти, а процес становлення та функціонування конкурентоспроможної особистості в їі цілісності. Дия пошуку шляхів вирішення поставценого завдання було здійснено огляд наукових публікацій за темою дослідження, щоб з'ясувати погляди фрахівців на можливості вирішення проблеми, що перебуває в 
центрі розгмяду.

Аналіз останніх досліджень і пубАікацій. Сучасні дослідники приділяють чимало уваги вивченню феномену конкурентоспроможності особистості: передусім ії формуванню, особливостям проявів тощо, як у теоретичному, так i практичному аспектах [1-25].

Теоретичні основи конкурентоспроможності особистості, з позицій сучасних наукових поглядів, детально і різнобічно розглянуто в працях таких вчених: А.В. Алексєєвої [1], Н.В. Ортікової [16], С.А. Подосіннікової [17], С.I. Савчук [23], а також у колективних монографіях [18] та ін. У них викладено теоретичні та методомогічні підходи до вивчення конкурентоспроможності особистості, виокремлено іiі основні складові, розглянуто природу даного феномену, наведено необхідні визначення, подано обгрунтування висвітлених положень та ін.

Стосовно головних аспектів конкурентоспроможної особистості, до них фахівці, що займаються даною проблемою, відносять наступні.

$\Lambda . В$. Галаган при розгляді проблеми формування конкурентоспроможності особистості фахівця вважає за необхідне враховувати економічний аспект проблеми [7]. Дана обставина зумовмена тим, що кожен фахівець, будь-якого профілю, який змушений працювати у сучасних умовах, передусім виступає суб'єктом ринкових економічних відносин. Звідси постає потреба надати майбутнім фахівцям необхідні знання про формування i функціонування ринку, особливості діяльності та взаємодії в умовах ринкової конкуренції та ін.

Багато публікацій на дану тему присвячено педагогічному аспекту проблеми. Зокрема, розвиток конкурентоспроможності особистості в системі освіти розглянуто в працях С.Н. Бегідової зі співавторами [4], М.Є. Бушуєвої [5], Т.А. Данилової [10], Н.В. Корнєйченко [12], С.Д. Рєзніка [20] та ін. У них висвітмено як актуальність даної проблеми в сучасних умовах, так і можливості щодо іiі вирішення у середніх загальноосвітніх і вищих навчальних закладах, 3 застосуванням як традиційних, так і інноваційних підходів.

Н.М. Черновол звертає увагу на необхідність врахування валеологічного аспекту проблеми конкурентоспроможності особистості [24]. Дана обставина зумовлена тим, що саме рівень здоров'я Аюдини виступає тим ресурсом, який дозволяє їй виконувати діяльність, а ії результати залежать від наявного стану здоров'я. Реальні умови конкуренції вимагають великих затрат зусиль, фізичних i психічних, що важливо враховувати при формуванні конкурентоспроможності особистості.

На профорієнтаційний аспект проблеми звертає увагу В.І. Шаповалов [25]. Згідно 3 сучасними науковими уявленнями, досягнути визначних результатів у певному виді діяльності здатна мише особистість, яка має до неї необхідні здібності. А саме визначні результати діяльності забезпечують як задоволеність роботою, так і успішність діяльності в умовах конкуренції.

Інші автори відзначають важливість врахування акмеологічного аспекту, зокрема: І.Н. Васильєв [6], Н.В. Кузьміна [14] та ін. Акмеологія, яка виникла у 20-х роках минулого століття, як розділ вікової психології, протягом останніх десятиліть еволюціонувала у самостійну наукову дисципліну, яка вивчає закономірності досягнення як високих професійних результатів, у різних сферах діяльності, так і в житті загалом.

Низка авторів вказує на важливість побудови раціональних стратегій забезпечення життєвого і професійного успіху; інформацію про це викладено у пубмікаціях: Т.В. Гурої [9], С.Р. Кові [11], Д. Колінза [13], О.Г. Романовського [22] та ін. Переважно це відомості про досвід мюдей, яким вдалося досягнути визначних результатів у певній сфері діяльності, проте $\epsilon$ також інформація про загальні закономірності досягнення життєвого і професійного успіху тощо.

Щодо можливостей розвитку конкурентоспроможності особистості, міркування про це висловлено в публікаціях: В.I. Андрєєва [2], М. Аткінсона [3], Т. Голві [8], А.М. Мітіної [15], С.Д. Рєзніка [19], С.М. Романової [21] та ін. У їхніх працях наведено дані про сучасні теоретичні та практичні підходи, а також ефективні технології розвитку конкурентоспроможності особистості.

Розгляд думок названих авторів та іхній аналіз не наводиться, оскільки 
здійснити навіть конспективний їх виклад не дозволяє обсяг даної публікації, проте вони враховані при формуванні підходу до вирішення проблеми.

Зустрічаються також інші погляди та підходи, проте вони дамеко не завжди видаються достатньо розробленими і обгрунтованими. Відтак, огмяд публікацій на дану тему на цьому можна завершити.

Виокремлення не вирішених раніше частин проблеми. Як засвідчив здійснений огляд публікацій за темою дослідження, окремі аспекти поставценої проблеми розглянуто достатньо повно, проте конкретних методик, придатних дмя формування конкурентоспроможності майбутніх фахових психологів у процесі навчання у ВНЗ, не виявцено, як $\mathrm{i}$ відповідних навчамьних спецкурсів для досягнення вказаної мети. Звідси постане необхідність проведення самостійного досиідження.

Виклад основного матеріалу досмідження. Формування раиіонального підходу до укладання спеикурсу. 3'ясування думок фахівців 3 приводу проблеми, яка перебуває в центрі розгмяду, дозволимо встановити, що, згідно $з$ сучасними науковими уявценнями, основою конкурентоспроможної особистості є не стільки їі конкретні психологічні особмивості, а передусім певні стратегії (як програми іiі соціальної взаємодії), які вона реалізує у процесі життєдіяльності (як у роботі за фахом, так і в процесі підготовки до неї). Дана обставина дозволила сформувати раціональний підхід до вирішення поставленої проблеми, який моделює процес формування конкурентоспроможності особистості фахівця, і полягає в наступному.

1. Спочатку студентам, після актуалізації проблеми, на вирішення якої спрямовано даний навчальний предмет, формування належної позитивної мотивації до його освоєння, потрібно надати знання про сутність явища конкурентоспроможності особистості, його психологічний вміст, складові та ін. Тобто необхідно висвітлити проблему, підходи до іï розгляду, наслідки їі наявності або ж успішного вирішення тощо. Зокрема, передусім доцільно належним чином висвітАити філософський і соціальний аспекти проблеми.
2. Після цього доречно ознайомити майбутніх фахових психологів із тим, як відбувається, згідно з сучасними науковими уявленнями, формування конкурентоспроможності особистості протягом життя, передусім у процесі виховання та навчання, як у загальноосвітніх закладах, так і в процесі подальшої фахової підготовки у ВНЗ. Тобто необхідно висвітиити педагогічний аспект проблеми, а також профорієнтаційний, як його невід'ємну складову.

3. Затим видається доцільним надати необхідні знання про головні аспекти і підходи до формування конкурентоспроможності особистості. До найважливіших аспектів, крім наведених раніше, необхідно віднести: економічний, валеомогічний, поведінковий і акмеологічний. Психологічний аспект не виділяється в

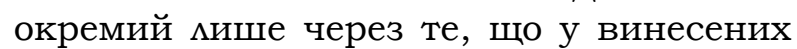
на розгляд аспектах у центрі уваги перебувають передусім їхні психомогічні компоненти.

4. Згодом, з огляду на необхідність забезпечення конкурентоспроможності майбутніх фахових психологів, як в особистісному, так і в професійному плані, необхідно ознайомити студентів 3 ефективними стратегіями досягнення життєвого та професійного успіху. Дця цього увагу викладу доречно максимально зосередити на вивченні досвіду тих мюдей, які досягли вершин життєвого успіху, як в особистісному, так i професійному плані (видатних вчених-психологів передусім). У даному випадку головну увагу слід зосередити на розкритті особистісного аспекту проблеми.

5. Нарешті, студентів-психологів потрібно ознайомити з реальними вимогами їхніх потенційних працедавців, як і 3 особливостями роботи практичних психологів у сучасних ринкових умовах. При цьому акцент слід зробити на тому, яким чином отримані в ході вивчення даного спецкурсу знання можна використати дмя побудови оптимальної індивідуальної стратегії досягнення життєвого та професійного успіху. Таким чином буде максимально розкрито мотиваційний аспект проблеми.

6. На завершення студентам необхідно надати знання про можливості щодо підвищення вцасної конкурентоспроможності, ознайомивши їх із сучасними техноцогіями розвитку потенціалу особистості; а також сформувати відповідні 
навички, необхідні для їхнього успішного застосування. Таким чином передбачено найповніше висвітлити поведінковий аспект проблеми.

Як відзначалося, надати студентам необхідні знання та вміння про основні стратегії формування i забезпечення конкурентоспроможності особистості фахівця, а також особливості їхньої реамізації у сучасних умовах було передбачено в процесі викладання спецкурсу, укладеного 3 врахуванням висвітлених положень. Було також передбачено, у ході освоєння студентами необхідних знань, сформувати у них необхідні дмя їхнього застосування практичні навички, що передбачено здійснити за допомогою спеціально розроблених, до кожної 3 прочитаних тем, практичних занять. На даний час цю роботу ще не завершено, крім цього, вона вимагає окремого розгАяду.

Структура розробленого навчального спещкурсу. Враховуючи результати проведеної роботи, було створено спецкурс, що передбачав здійснити оптимізацію й активізацію процесу формування конкурентоспроможності особистості майбутніх фахових психологів. Навчальний спецкурс "Психологія конкурентоспроможної особистості" розраховано на 64 год. аудиторних занять (32 год. мекційних і 32 год. практичних); він містить наступні розділи, теми і питання, що розглядаються.

\section{І. Вступ до курсу}

Тема 1. Поняття і сутність конкурентоспроможності особистості. (Розуміння поняття "конкурентоспроможна особистість". Сфери розвитку конкурентоспроможної особистості. Сфера діяльності конкурентоспроможної особистості. Сфера спілкування конкурентоспроможної особистості. Особистісна сфера і самосвідомість конкурентоспроможної особистості. Результати і наслідки конкурентної взаємодії в соціумі. Головні аспекти проблеми дослідження КСО).

II. Формування конкурентоспроможності особистості в процесі виховання і навчання.

Тема 2. Формування основ майбутньої конкурентоспроможності особистості в процесі дошкільного виховання. (Формування особистості з позицій етнопедагогіки. Особливості підготовки до са- мостійного життя з позицій різних педагогічних підходів. Вплив дошкільного виховання особистості на іiі подальший життєвий шлях. Сучасні підходи до виховання в розвинених країнах світу. Необхідність реформування вітчизняної системи дошкільного виховання).

Тема 3. Формування конкурентоспроможності особистості в системі загальної середньої освіти. (Особливості підготовки до подальшого самостійного життя в системі загальної середньої освіти. Розвиток конкурентоспроможності особистості в системі загальної освіти. Організація конкуренторозвиваючого навчального процесу в сучасній школі. Досвід формування конкурентоспроможності в системі загальної середньої освіти розвинених країн світу).

Тема 4. Адекватний вибір майбутньої професії як стратегія забезпечення життєвого успіху і конкурентоспроможності особистості. (Проблема життєвого і професійного вибору особистості. Побудова життєвих пцанів і вибір професії старшокласниками. Детермінанти професійного вибору. Помилки при виборі профеcii. Компоненти успішного вибору. Профорієнтаційна робота в сучасній школі: iï завдання і можливості. Професійна психодіагностика. Професійна консультація. Значення вдалого вибору професії у житті Аюдини і формуванні іiі конкурентоспроможності).

Тема 5. Формування конкурентоспроможності особистості в системі вищої освіти. (Розвиток конкурентоспроможності особистості в системі вищої освіти. Види компетентності та їх формування в процесі навчання. Вимоги ринку праці до фахівця. Організація конкуренторозвиваючого навчального процесу у ВНЗ. Сучасні можливості розвитку конкурентоспроможності майбутнього фахівця у ВНЗ: досвід розвинених зарубіжних країн).

III. Головні аспекти і підходи до фрормування конкурентоспроможності особистості.

Тема 6. Економічний аспект конкурентоспроможності особистості. (Сутність економічної конкуренції. Особливості економічної конкуренції. Види економічної конкуренції. Функції конкуренції. Методи економічної конкуренції. Ринок монополістичної конкуренції. Теорії 
економічної конкуренції. Економічна компонента фахової діяльності. Конкуренція в сучасному суспільстві. Значення конкуренції).

Тема 7. Валеологічний аспект конкурентоспроможності особистості. (Сучасна концепція здоров'я. Фізичне здоров'я та його складові. Психічне здоров'я та його складові. Соціальне здоров'я та його складові. Професійне здоров'я. Діагностика показників здоров'я. Здоровий спосіб життя та його складові. Формування навичок здорового способу життя. Сучасні здоров'язберігаючі й оздоровчі технології).

Тема 8. Акмеологічний підхід конкурентоспроможності особистості. (Акмеомогія як галузь психологічного знання. Конткурентоспроможність особистості 3 позицій акмеології. Структура акмеологічного підходу до розвитку професіоналізму. Акмеологічні закони. Акмеологія професійного становцення. Шиях до професійної майстерності з позицій акмеологіі).

Тема 9. Поведінковий аспект конкурентоспроможності особистості. (Проблема становлення і вибору життєвої позиції особистості. Життєва позиція і іï реалізація в професійній діяльності. Вплив життєвої позиції особистості на ії життя і професійну діяльність. Пасивна позиція особистості і їі реалізація в професійній діяльності. Активна позиція особистості і ї̈ реалізація в професійній діяльності. Особливості організації професійної діяльності з врахуванням поведінкового аспекту).

IV. Стратегії досягнення життєвого i професійного успіху як шиях забезпечення конкурентоспроможності особистості.

Тема 10. Стратегія успіху Ф. Скіннера: особливості та специфіка реалізації. (Життєвий шлях Ф. Скіннера і вибір професії. Навчання і робота над освоєнням фаху психолога. Шиях до вершин професійної майстерності. Наукова діяльність і розробка над власними теоріями. Теорії Скіннера і його внесок у психологічну науку. Соціальні теорії Скіннера. Результати діяльності та суспі$\Lambda$ ьне визнання).

Тема 11. Стратегія успіху за А. Маслоу: особливості побудови та реалізації. (Освоєння фаху А. Маслоу. Розроб- ка власних наукових теорій. Дослідження особистостей, що самоактуалізуються. Теорія самоактуалізації і ії вплив на наукову психологію. Шиях до самоактуалізації і досягнення життєвого та професійного успіху. Особливості та наслідки реамізації стратегії самоактуалізації особистості. Складові самоактуалізації. Визначення рівня самоактуалізації. Теорія i практика самоактуалізації особистості 3 позицій сьогодення).

Тема 12. Стратегії успіху за С. Кові: теоретичні основи та особливості побудови. (Дослідження стратегій життєвого і

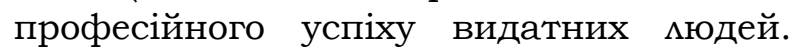
Принципи побудови ефективних стратегій досягнення успіху. Основні навички, необхідні для досягнення успіху та іхній розвиток. Робота над собою з позицій досягнення успіху. Налагодження взаємодії з оточуючими з позицій досягнення успіху. Організація професійної діяльності з позицій досягнення успіху).

V. Вимоги ринку праці до фрахівця в сучасних умовах та забезпечення його конкурентоспроможності.

Тема 13. Особливості працевцаштування професійного психолога у ринкових умовах. (Вимоги працедавців до фахового психолога. Критерії розвитку конкурентоспроможності особистості. Основи фахової самопрезентації. Стратегії пошуку роботи фахових психологів).

Тема 14. Побудова індивідуальної стратегії забезпечення життєвого і професійного успіху та особливості їі реалізації. (Компоненти індивідуальної стратегії та умови їхньої успішної реалізації. Детермінанти життєвого та професійного успіху та іх врахування при побудові стратегіi. Індивідуально-психологічні особливості та їхнє врахування при побудові стратегії. Побудова індивідуальної стратегії. Робота над реалізацією індивідуальної стратегії. Оцінка результатів та внесення коректив при роботі за індивідуальною стратегією).

VI. Технології підвищення конкурентоспроможності особистості в процесі самовдосконалення.

Тема 15. Психологічні засади розвитку конкурентоспроможності особистості. (Базові характеристики конкурентоспроможності особистості. Технологія розвитку конкурентоспроможності. Змісто- 
вий аспект конкурентоспроможності. Емоційний аспект конкурентоспроможності. Поведінковий аспект конкурентоспроможності. Інтелектуальний аспект конкурентоспроможності. Професійна деформація i конкурентоспроможності особистості).

Тема 16. Коучінг як інтерактивна технологія розвитку потенціалу особистості. (Поняття про коучінг. Коучніг як освітня технологія. Коучніг в професійній діяльності. Організація коучінгу для саморозвитку. Організація коучінгу в процесі навчання. Організація коучінгу в професійній діяльності).

Апробація розробленого спецкурсу була здійснена протягом осіннього семестру 2016/2017 навчального року, протягом якого спецкурс "Психологія конкурентоспроможної особистості" викладався магістрам спеціальності "Психологія", (у дещо скороченому вигляді: 16 год. мекційних і 32 год. практичних занять), що дає підстави констатувати наступне. Спецкурс викликав інтерес у майбутніх фахових психологів, більшість із них виявили бажання не мише освоїти набуті знання, але й використати їх для підвищення власної конкурентоспроможності шляхом активізації особистісного розвитку. Вони не мише активно долучалися до обговорення винесених на розгляд питань з запропонованих тем, але й самі займалися пошуком додаткового матеріалу, який використовували для виступів під час практичних занять тощо. Найактивніші навіть робили конструктивні пропозиції щодо вкАючення у спецкурс нових тем, розгляду запропонованих питань під іншим ракурсом, а також пропонували внести певні зміни у процес викладання та ін. Загалом, необхідно відзначити, що інформація як про хід, так і особливості викладання спецкурсу, а також про реакцію та ставлення до нього студентів, (як і про необхідні корективи), заслуговує окремої публікаціï.

Після апробації даного курсу передбачено здійснити оцінку його ефективності, потім доповнити новими матеріамами; а також завершити роботу з розробки до кожної теми практичних занять, які б передбачали застосування нових підходів як до виховання i навчання майбутніх фахівців, так i формування конкурентоспроможності їхньої особистості в сучасних умовах.

Висновки і перспективи подамьших досліджень.

1. Аналітичне дослідження проблеми, яка перебуває у центрі розгляду, дозвомимо констатувати, що сучасний стан розвитку психологічної науки і практики дозволяє розробити раціональний підхід

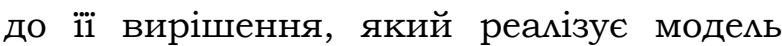
процесу формування конкурентоспроможності особистості фахівця.

2. Сформований у результаті проведеного дослідження підхід може бути реалізований за допомогою складання і викладання майбутнім фаховим психоцогам навчального спецкурсу "Психологія конкурентоспроможної особистості", який передбачено читати магістрампсихологам.

3. Апробація розробленого та впровадженого спецкурсу дозволяє стверджувати, що внаслідок його викладання відбувається активізація і оптимізація процесу формування конкурентоспроможності майбутніх фахових психологів, оскільки дозволяє зробити його усвідомменішим і цілеспрямованішим, викликає зацікавленість у студентів і бажання скористатися отриманими знаннями та набутими вміннями.

У майбутньому передбачено провести емпіричне дослідження, дия з'ясування ставлення студентів до даного спецкурсу, з тим, щоб внести у нього необхідні корективи, враховуючи як наявний досвід його викладання, так і побажання студентів.

\section{Список бібліографічних посимань}

1. Алєксєєва А.В. Професійна конкурентоздатність особистості: психомогічний аспект. Психологія праиі та управління: зб. наукових праць VI Міжнародної науково-практичної конференції. Ч. 1. Київ: ІПК ДСЗУ, 2009. С. 147-153.

2. Андреев В.И. Конкурентология: учебный курс дмя творческого развития конкурентоспособности. Казань: Центр инновационных технологий, 2004. 468 с.

3. Аткинсон М., Рае Ч.Т. Пошаговая система: Наука и искусство коучинга. Київ: Companion Group, 2009. 256 с

4. Бегидова С.Н., Хазова С.А., Мозгот В.Г. Развитие конкурентоспособной мичности учащихся как целевой ориентир системы образования. URL: http://cyberleninka.ru/article/n/razvitiekonkurentosposobnoy-lichnosti-uchaschihsya-kaktselevoy-orientir-sistemy-obschego-obrazovaniya.

5. Бушуева М. Е. Психологические основы становцения конкурентоспособного специалиста в процессе обучения. URL: http:/ /www.sworld.com.ua/konfer27/742.pdf. 
6. Васильев И.Н. Конкурентоспособность как акмеологический феномен. Наука u современность. Психологические науки. 2010. C. 69-72.

7. Галаган $\Lambda$.В. Сутність конкурентоздатності Аюдини як економічного суб'єкта. URL: http://www.nbuv.gov.ua/old_jrn/soc_gum/znpip/ 1/2010_25/Galagan.pdf.

8. Голви Т. Максимальная самореализация: Работа как внутренняя игра. Фокус, обучение, удовольствие и мобильность на рабочем месте. М.: А^ьпина Бизнес Букс, 2007. 264 с.

9. Гура Т.В. Психологія досягнення успіху як напрям розвитку конкурентоспроможності майбутніх ІТ-рахівців. Теорія $i$ практика управління соиіальними системами. 2013. № 4. C. $105-111$.

10. Данилова Т.А. Формирование конкурентоспособности цичности в образовательном процессе ВУЗа. Известия Российского государственного педагогического университета uм. А.И. Гериена. 2008. №88. С. 270-275. URL: https://cyberleninka.ru/article/n/formirovaniekonkurentosposobnoy-lichnosti-v-obrazovatelnomprotsesse-vuza.

11. Кові С. Р. Сім звичок надзвичайно ефективних Аюдей. 2-е вид., стер. Харків: Клуб Сімейного Дозвіляя, 2016. 384 с.

12. Корнейченко Н. В. Конкурентоспособность будущего специалиста как показатель качества его подготовки. Вестник АГТУ. 2007. № 6. URL: http://cyberleninka.ru/article/n/konkurentosposo bnost-buduschego-spetsialista-kak-pokazatelkachestva-ego-podgotovki

13. Комлінз Д., Хансен М.Т. Величні за власним вибором. Київ: Наш Формат, 2016. 368 с.

14. Кузьмина Н.В. Акмеологическая теория повышения качества подготовки специалистов образования. М.: ИЦПКС, 2001. 144 с.

15. Митина $\Lambda$.М. Психология развития конкурентоспособной мичности. М.: Московский психолого-социальный институт; Воронеж: МОДЭК, 2002. 400 с.

16. Ортікова Н.В. Теоретичний аналіз проблеми формування конкурентоспроможності молодих спеціалістів у сучасних ринкових умовах. Науковий часопис Національного пед. ун-ту ім. М. П. Драгоманова. Київ, 2006. Вип. 15(39). C. $188-191$.

17. Подосинников С.А. Психология конкурентоспособности: монография. Астрахань: Астраханский университет, 2008. 84 с.

18. Психологічні аспекти професійної підготовки конкурентоздатних фахівців: монографія / Дегтярьова Г.С., Козяр М.М., Матійків I.М., Руденко $\Lambda$. А., Шиделко А.В.; за ред. Руденко $\Lambda$.А.. Київ, 2012. $170 \mathrm{c}$

19. Резник С.Д., Сочилова А.А. Основы мичной конкурентоспособности. Учеб. пособие. М.: ИНФРА-М, 2010. $181 \mathrm{c.}$

20. Резник С.Д. Конкурентоспособность выпускника российского вуза: системы и механизмы формирования: монография. Пенза, 2012. 283 с.

21. Романова С.М. Коучінг як нова технологія в професійній освіті. URL: http://ecobio.nau.edu.ua/index.php/VisnikPP/arti cle/viewFile/2145/2136

22. Романовський О.Г., Михайличенко В.Є. Філософія досягнення успіху. Психологічний аспект: Підручник. Харків: ХПI, 2007. 592 с.

23. Савчук С.И. Основы теории конкурентоспособности. Мариуполь: Рената, 2007. $519 \mathrm{c}$

24. Черновол Н.М. Валеологічні аспекти професійної підготовки студентів. Педагогіка $i$ психологія профресійної освіти. 2012. № 2. С. 94-99.

25. Шаповалов В.И. Конкурентоспособность специамиста. Высшее образование в России. 2005. № 10. C. 96-101.

\section{References}

1. Alyeksyeyeva, A.V. (2009). Professional competitiveness of the individual: the psychological aspect. Psychology of Labor and Management: a collection of scientific works of the 5th International Scientific and Practical Conference. Part 1. Kyiv: IPC SSSU. 147-153. (in Ukr).

2. Andreev, V.Y. (2004). Competitiveness: a training course for creative competitiveness development. Kazan: Center for Innovative Technologies. 468 p. (in Rus).

3. Atkynson, M., Rae C.T. (2009). Step-by-Step System: Science and Art of Coaching. Kyiv: Companion Group. 256 s. (in Rus).

4. Begydova, S., \& Khazova, S., \& Mozgot, V. Development of the competitive personality of students as a target orientation of the system of education. Retrieved from http://cyberleninka.ru/article/n/razvitie-

konkurentosposobnoy-lichnosti-uchaschihsya-kaktselevoy-orientir-sistemy-obschego-obrazovaniya (in Rus).

5. Bushueva, M.E. Psychological foundations of becoming a competitive specialist in the learning process. Retrieved from http://www.sworld.com.ua/konfer27/742.pdf (in Rus).

6. Vasiliev, Y.N. (2010). Competitiveness as an acmeological phenomenon. Science and modernity. Psychological sciences. 69-72. (in Rus).

7. Galagan, L.V. (2010). The essence of the competit veness of the people of the economical sub-category. Retrieved from http://www.nbuv.gov.ua/old_jrn/soc_gum/znpip/ 1/2010_25/Galagan.pdf (in Ukr).

8. Golvy, T. (2007). Maximum self-realization: Work as an internal game. Focus, training, pleasure and mobility in the workplace. Moskow: Al'pyna Byznes Buks, 264 s. (in Rus).

9. Gura, T.V. (2013). Psychology of success as a direction for the development of the competitiveness of future IT professionals. The theory and practice of social systems management. 4. 105-111. (in Ukr).

10. Danylova, T.A. (2008). Formation of the competit veness of the individual in the educational process of the university. News of the Russian State Pedagogical University. A.I. Herzen. 88. 270-275. Retrieved from http://cyberleninka.ru/article/n/formirovaniekonkurentosposobnoy-lichnosti-v-obrazovatelnomprotsesse-vuza. (in Rus).

11. Kovi, S.R. (2016). Seven is the most inveterate efektivnyh people. 2-ed., ster. Kharkiv: Family Leisure Club. 384 s. (in Ukr).

12. Korneychenko, N.V. (2007). Future competitiveness as an indicator of the quality of its training. Herald ASTU. 6.6 Retrieved from http://cyberleninka.ru/article/n/konkurentosposo bnost-buduschego-spetsialista-kak-pokazatelkachestva-ego-podgotovki (in Rus).

13. Kollinz, D. \& Khansen, M.N. (2016). Great on your own choice. Kyiv: Our Format, 368 s. (in Ukr).

14. Kuzmina, N.V. (2001). Akmeologicheskaya theory of improving the quality of training specialists in education. Moskow: YTsPKS. 144 s. (in Rus).

15. Mytyna, L.M. (2002). Psychology of development of competitive personality. Moskow: Moscow Psychological and Social Institute; Voronezh: MODEK. 400 s. (in Rus). 
16. Ortikova, N.V. (2006). Theoretical analysis of the problem of forming the competitiveness of young specialists in modern market conditions. Scientific journal of the National Pedagogical University named after M.P. Drahomanov. Kyiv. 15 (39). 188191. (in Ukr).

17. Podosynnykov, S.A. (2008). Psychology of competitiveness: monograph. Astrakhan: Astrakhan University. 84 s. (in Rus).

18. Psychological aspects of professional training of competitive specialists: monograph (2012) / Degtyareva, G.S., Kozyar, M.M., Matiikov, I.M., Rudenko, L.A., Shidelko, A.V.; In L.A. Rudenko (Ed.). Kyiv. 170 s. (in Ukr).

19. Reznyk, S.D. \& Sochylova, A.A. (2010). Fundamentals of personal competitiveness. Moskow, YNFRA-M. 181 s. (in Rus).

20. Reznyk, S.D. (2012). Competitiveness of the graduate of the Russian university: systems and mechanisms of formation. Penza, 283 s. (in Rus).
21. Romanova, S.M. Coaching as a new technology in vocational education. Retrieved from http://ecobio.nau.edu.ua/index.php/VisnikPP/arti cle/viewFile/2145/2136 (in Ukr).

22. Romanovs'kyy, O.G. \& Mykhaylychenko, V.Ye. (2007). The philosophy of success. Psychological aspect. Kharkiv: NTU "KhPI". 592 s. (in Ukr).

23. Savchuk, S.Y. (2007). The fundamentals of the theory of competitiveness. Maryupol: Renata. 519 s. (in Rus).

24. Chernovol, N.M. (2012). Valleological aspects of professional training of students. Pedagogy and psychology of professional education. 2. 94-99. (in Ukr).

25. Shapovalov, V.Y. (2005). Competitiveness of a specialist. Higher education in Russia. 10. 96-101. (in Rus).

\section{Ph.D in Psychology, Associate Professor of the Theoretical and Practical Psychology Department, National University "Lviv Polytechnic" \\ e-mail: yurvin@ukr.net}

\section{ELABORATION OF THE EDUCATIONAL SPECIAL COURSE "PSYCHOLOGY OF A COMPETITIVE PERSON"}

\begin{abstract}
Introduction. The necessity of activity in the current market economy conditions requires the approaches to training of specialists of different profiles to be changed. This also applies to practical psychologists who have to work under the reality when their services have not been sufficiently demanded by our society yet. Under these circumstances, a professional psychologist needs not only to gain an appropriate level of professional competence, but also to find an appropriate sphere for applying his/her knowledge and skills since during previous decades psychologists were not involved in various sectors of the national economy. Our country faced challenges of the world community and its economic system, consequently it requires social development intensification, and the main condition for adapting to existing realities is the formation of a high competitiveness of specialists. Hence, there is the necessity to organize training of psychologists at domestic HEE so as to provide such future specialists an ability to operate at the labour market in competitive conditions.
\end{abstract}

The purpose is to clarify the existing opportunities for increasing the competitiveness of future professional psychologists during their training at HEE, to develop and implement a rational approach for the elaboration of a specific training course and to elaborate such a special course.

Methods. Analysis, synthesis, specification, modelling, generalization.

Results. Following the literature review in respect the study topic the views of specialists on the formation of the personal competitiveness at HEE in modern conditions are established. Referring to them, a special course "Psychology of a Competitive Personality" intended for future professional psychologists was elaborated. The approbation of a proposed course in the real educational and training process aimed at training of future professional psychologists at HEE was performed.

Originality. Based on the results of our study, a special course "Psychology of a Competitive Personality" was elaborated. It provides for optimization and activation of formation of the personal competitiveness of future professional psychologists. The developed pattern of formation of professional competence of future psychologists includes main topics necessary for achieving the set goal; for each topic, its main discussed issues are specified. The pattern of the process of formation of a competitive personality adequately reproduces the actual process of training future professional psychologists at HEE. Upon its further testing and updating it can be recommended for introduction into the educational and training process.

Conclusion. An analytical study of the problem being the focus of our attention made it possible to confirm that the current state of psychological science and practice allows one to formulate and implement a rational approach to its solution. The resulting research approach can be implemented by developing and delivering the training course "Psychology of a Competitive Personality" for future professional Master psychologists. The approbation of the developed and implemented special course suggests that as a result of its delivering we can observe the activation and optimization of forming of the competitiveness of future professional psychologists, as it allows it to make it more informed and purposeful, arises interest in students and the desire to take practical advantage of the knowledge and skills gained.

Annotation. The possibilities of improving the competitiveness of the future professional psychologists in the course of their studies at the HEE are considered in the article. The initial assumptions of the study were formulated; an overview of scientific publications on this topic was made as a result of the opinions of experts on the problem and its possible solutions were found out. A rational approach to solving this problem was formed on the basis of the data obtained; its use developed A special course designed to form the competitive future psychologists in the course of their studies at the HEE was elaborated. The information on testing the developed special course was given. The conclusions of the carried out in vestigation were made and the prospects for further investigation in this direction were outlined.

Keywords: the future professional psychologists training; work in market conditions; the labour market; competition; educational special course; psychology of a competitive personality; optimization of the specialists' training process. 